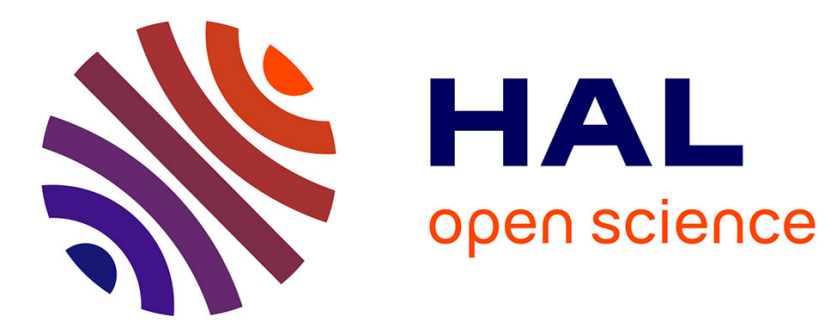

\title{
COMPACTION AND SPRINGBACK BEHAVIOUR OF SPRAY DRIED GRANULATES
}

\author{
C. Hahn
}

\section{To cite this version:}

C. Hahn. COMPACTION AND SPRINGBACK BEHAVIOUR OF SPRAY DRIED GRANULATES. Journal de Physique Colloques, 1986, 47 (C1), pp.C1-91-C1-96. 10.1051/jphyscol:1986114 . jpa00225538

\section{HAL Id: jpa-00225538 https://hal.science/jpa-00225538}

Submitted on 1 Jan 1986

HAL is a multi-disciplinary open access archive for the deposit and dissemination of scientific research documents, whether they are published or not. The documents may come from teaching and research institutions in France or abroad, or from public or private research centers.
L'archive ouverte pluridisciplinaire HAL, est destinée au dépôt et à la diffusion de documents scientifiques de niveau recherche, publiés ou non, émanant des établissements d'enseignement et de recherche français ou étrangers, des laboratoires publics ou privés. 
JOURNAL DE PHYSIQUE

Colloque C1, supplément au $\mathrm{n}^{\circ} 2$, Tome 47 , février 1986

page $c 1-91$

COMPACTION AND SPRINGBACK BEHAVIOUR OF SPRAY DRIED GRANULATES

\author{
C. HAHN
}

Hutschenreuther $A G$, Central Research and Development, D-8672 SeIb, F.R.G.

\begin{abstract}
Résumé - Les réactions de densification et de déformation résiduelle des granulés séchés par atomisation ont été mesurées dans une cellule à pressage, équipée de capteurs de mesure. Ces réactions ont été enregistrées simultanément par un centre informatique de traitement analogue. Les informations ainsi obtenues ont éte interprêtêes sous forme de diagramme semi-logarithmique. On y a constaté des graphiques caractẹristiques, dont le tracé de lignes était fonction des qualitês du granulé, et qui font actuellement l'objet d'une discussion. La vitesse de pressage et la pression de façonnage ont également été variées, et on a examiné l'influence de ces alterations sur la densification et la déformation résiduelle. L instrumentation appliquée peut servir, dans la pratique, à effectuer rapidement des mensurations comparatives sur le plan des qualités de pressage de la fabrication de granulé en cours.

Abstract - Measurements of compaction and springback behaviour have been carried out on spray dried granulates. A unidirectional compacting tool with two electromechanical transducers on bottom and top has been used, together with an Instron testing machine and online with a laboratory computer. The results have been figured in semilogarithmic plotter diagrams of log pressure vs density. The diagrams have been shown characteristic curves and in relation to the properties of granulates certain differences in these lines were observed. The influences of humidity, grain size distribution, density and hardness of granules have been studied, as well as speed of densification and amount of pressure. Under more practical aspects, densification and springback behaviour can be characteri sed by certain parameters of compaction curves, by yield point $Y$, slope and amount of springback after release of pressure. Therefore this instrumentation is very suitable for rapid testing of several lots of granulate with respect to differences.
\end{abstract}

I - Introduction and objectives

Dry pressing of powders using metal dies is extensively employed in the ceramic industry for manufacturing a wide variety of products and components. It is common for the powders to be converted into granulates in a preliminary step by adding organic binders and spraydrying slips. This process yields grains which are almost spherical 
and have a diameter in the range 50-500 $\mu \mathrm{m}$, two properties which improve flowing and pressing behaviour. Many researchers have worked on the problems encountered in dry pressing granulates, although the detailed processes are complex and fundamental elements are often still lacking. A number of papers have been published in recent years on theoretical and experimental aspects of the pressing behaviour of granulates. Some of the major publications are cited here as representative. Numerous papers have dealt with compaction models and equations describing the powder compaction mechanisms, of which more than 20 are now known. About 15 of these papers are reviewed in $/ 1 /$. The first effort to describe powder compaction by pressure/density diagrams goes back to /2/. /3/ contains the first indications that correlations must be present. /4/ describes the effect of pressure and moisture on elastic springback and feasible pressing densities for spray-dried earthenware compounds. The causes of elastic springback in mouldings after removal are discussed in $/ 5 / . / 6 /$ deals with the compaction of spray-dried agglomerates and struotures in the moulding, and looks at compaction curves using semilogarithmic plots of pressure against density. The effect of various binder systems on the pressing behaviour of spray-dried ferrites is studied in $/ 7 /$, and 18/ deals in detail with compaction and springback processes during isostatic pressing. /9/ looks at the effects of polyvinyl alcohol and moisture on the compaction of spray-dried titanate and ferrite powders. The effect of pressing rate, moisture and binder additions on compaction are discussed in $/ 10 /$. /11/ describes the benefits of plotting pressure/density diagrams and deriving quantitative results. The effect of binders on the compaction process and the pore structure of mouldings is studied in /12/. /13/ reports correlations between grain size distribution, moulding pressure and density of the mouldings. In /14/ the compaction process is reduced to a single empirical equation $p-P y=m \ln \left(P / P_{y}\right)$, where $m=$ empirical slope beyond $P_{y}, P_{y}=$ pressure at the yield point and $P_{y}=$ density at the intersection of the high - and low - pressure inies.

/15/ deals with the effects of organic binders on grain hardness and compaction, and $/ 16 /$ reviews the importance of agglomerates in ceramic process technology, particularly during pressing. Finally, /17/ looks at problems with springback and their causes.

our present knowledge of dry pressing granulates, as outlined in the literature referred to above, is affected by the need to extract information on the compaction process from laborious series of test pressings. As a result, the effects of granulate properties on compaction behaviour have inevitably been studied as individual examples, rather than systematically. The objective of the present paper is to present a simultaneous study of the compaction and springback behaviour of spray-dried granulates and to establish the interrelationships of granulate properties and pressing behaviour. The granulate is described in terms of its moisture, grain size distribution, grain hardpess and bulk density.

\section{I - Experimental}

An Instron universal testing machine with cylindrical die was used for testing. A traverse speed of $600 \mathrm{~mm} / \mathrm{min}$ was chosen, corresponding to conventional pressing rates in production presses. The top and bottom of the die were both fitted with electromechanical transducers, which were linked by charge amplifiers and an analogue/digital converter to a computer with two floppy disk drives and plotter. This simultaneously recorded the loads on both sides of the moulding and plotted the log pressure $P$ vs density $D$ semilogarithmic compaction diagram. The computer was programmed to allow for the traverse rate. After a programmable maximum load has been reached, the traverse 
moves in the opposite direction with constant speed. The relaxation behaviour in the direction of pressing is recorded until the pressure has been fully released. Figure 1 shows the data capture system, which made possible the first simultaneous recording of compaction and springback responses of mouldings during pressing.

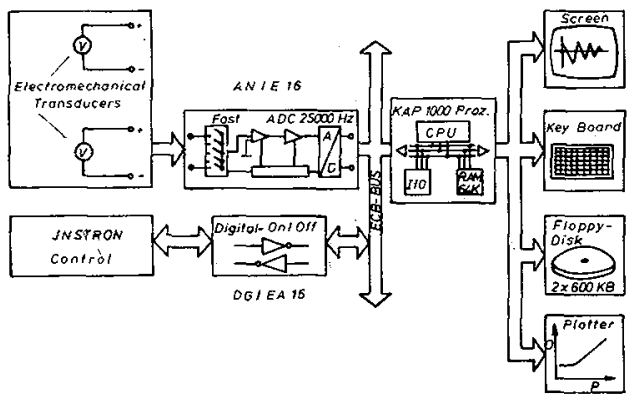

Fig. 1: - Block diagram of measurements registration

Figure 2 shows the compaction and relaxation diagram characterised by two compaction phases I and II and a springback phase III. Phase I involves grain rearrangement with slip processes yielding improved configuration and reduced pore space between grains. Phase II is characterised by plastic deformation, cracking and disintegration of the grains with reduction in pore space. Phase III describes elastic springback of the moulding during pressure release.

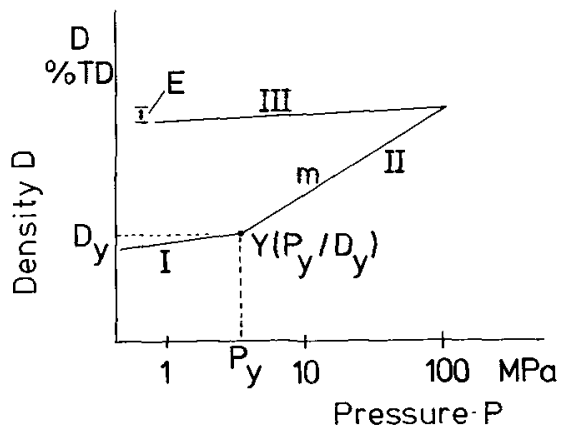

Fig. 2: - Typical diagram Ig pressure P vs density $D$ (y = Vield Point)

III - Discussion of results

The effects of pressing rate and pressure on compaction and springback are summarised in figure 3 . The semilogarithmic density/pressure diagram shows both density and springback increasing linearly with pressure. Similar linearity is observable in the semilogarithmic plot of springback against pressing speed, but density declines with increasing pressing speed. 
The effects of granulate properties were studied using specially prepared granulates. By way of example, figure 4 shows the effects of granulate moisture and grain size on density and springback. Density and springback increase with higher moisture levels, and decrease with smaller grain size.

Granulate properties, the compaction coefficient $Y\left(D_{y} / P_{y}\right)$, slope $m$ and

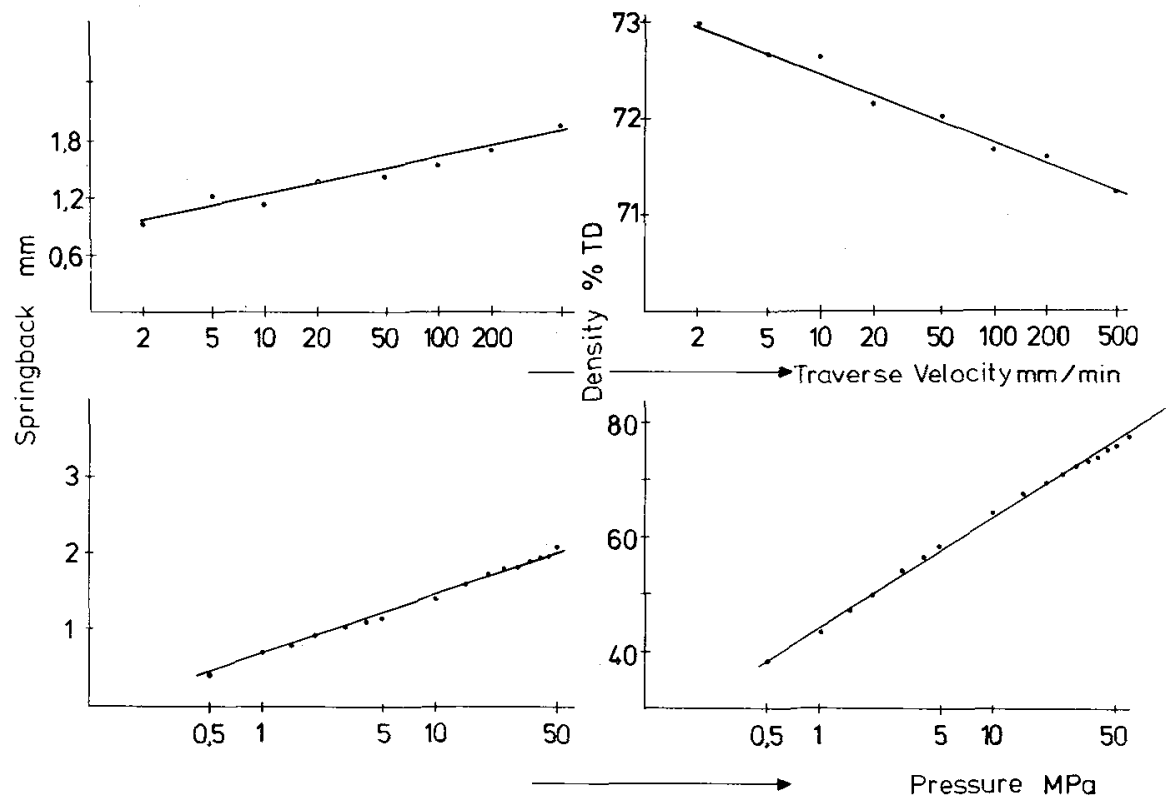

Fig. 3: - Influence of pressure and traverse velocity on springback and density

percentage springback $E$ were studied using about 80 granulates from commerc i a l l y / produced batches of porcelain body. A correlation matrix was calculated for the effect of properties such as moisture, average grain size, slope of the RRS cumulative size distribution curve, grain hardness and bulk density on pressing parameters such as $D_{y} / P_{y}, m$ and $E$. This showed an absence of correlation between moisture and pressing parameters (it should be noted that there was a very limited range of variation), while variation in bulk density and grain hardness emerged as decisive for pressing parameters. Bulk density correlates with both $D_{y}$ and $P_{y}$, and both bulk density and grain hardness correlate with the slope $m$ of the compaction curve. There is also correlation between average grain size and $D_{y}$ (density at the transition point).

This shows the critical importance for compaction and springback behaviour of mouldings of variations in bulk density, grain hardness and average grain size of commercially/produced granulates.

It may therefore be concluded that the instrumental arrangement shown is suitable for direct testing of powder properties during granulate production to determine pressing properties, so that variations can be corrected by adjustment to the spray dryer. It is also suitable for direct measurement of the compaction and springback behaviour of 
granulates, which is particularly important in development work and granulate monitoring in commercial-scale production.

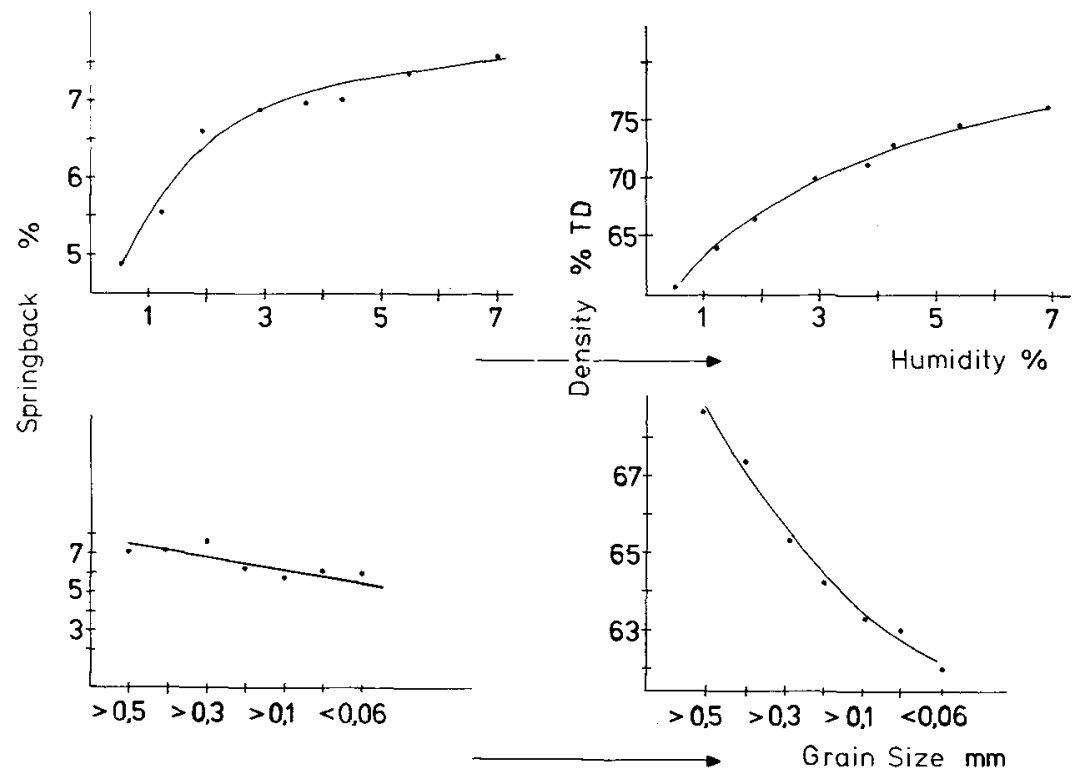

Fig. 4: - Influence of humidity and grain size on springback and density

IV - References

/1/ Kawakita, K. und Lüdde, H., Powder Technol. 4 (1970/71) 61.

/2/ Niesz, D. E., Bennet, R. B. and Snyder, M. J., Amer. Ceram. Soc. Bul1. 51 (1972) 677 .

/3/ Bruch, C. A., AichEJ 8 (1967) 44.

/4/ Price, W.M., in "Proceedings of the First International Conference on the compaction and Consolidation of Particulate Matter", Edited by A.S. Goldberge, The Powder Advisory Center, London (1973) /5/ Frisch,B., Thiele,W.R., Ber.Dt.Keram.Ges. 54, (1977) 224.

$16 /$ Lukasiewicz, S. J. and Reed, J. S., Amer. Ceram. Soc. Bull. 57 (1978) 798 .

/7/ Harvey, J. W. and Johnson jr. D. W., Amer. Ceram. Soc. Bull. $59(1980) 637$.

78/ Melzer, D., Freiberger Forschungsheft, A 626, VEB Deutscher Verlag für Grundstoffindustrie, Leipzig (1980).

19/ Brewer, A. J., Moore, R. H. and Reed, J. S., Amer. Ceram. Soc. Bull. 60 (1981) 212.

$110 /$ youshaw, R. A. and Halloran, J. W., Amer. Ceram. Soc. Bull. 61 (1982) 227.

$111 /$ Messing, G.L., Markhoff, C. J. and Coy, L. G., Amer. Ceram. Soc. BuII. 61 (1982) 857.

$/ 12 /$ Dimilia, R.A. and Reed, J. S., Jour. Amer. Ceram. Soc. 66 (1983) 667 .

/13; Dynys, F. W. and Halloran, J.W., Jour. Amer. Ceram. Soc. 66 (1983) 655 . 
/14/ Frey, R. G. and Halloran, J. W., Jour. Amer. Ceram. Soc. 67 (1984) 199.

$/ 15 /$ Nies, C. W. and Messing, G. L., Jour. Amer. Ceram. Soc. 67 (1984) 301.

/16/ Halloran, J. W., Advances in Ceramics 9 (1984) 67.

/17/ Schulle, W. und Melzer, D., Sprechsaal 117 (1984) 890 . 